\title{
Fresh hope for German stem-cell patent case
}

The German federal supreme court has referred a controversial and already lengthy patent dispute about human embryonic stem (hES) cells to the European Court of Justice.

The move might drag out the case - first brought to the German patent court in 2004 - for another two years. But it could be worth the wait, says Oliver Brüstle, director of the Institute of Reconstructive Neurobiology at the University of Bonn and owner of the patent in question. He hopes that a ruling from the European court will finally settle some of the uncertainties that hamper stem-cell scientists in his country.

German laws governing $\mathrm{hES}$ cell research are among the most restrictive in Europe. European patenting rules are meant to guide national legislation, but they include some statements that opponents and proponents of hES research can interpret in different ways - in particular, that patenting should not be allowed for procedures that are immoral or threaten public order.

The disputed patent was awarded to Brüstle by the German patent office in 1999. "It's crazy that It covers a technique for generating enting your cell lines, which researchers in methods is deemed to be contrary to public order." Germany are allowed to use. The method is a first step in generating neurons that could be used clinically to repair damage to the brain and spinal cord.

In 2004, Greenpeace lodged an objection to the patent on the grounds that the $h E S$ cell lines originated from fertilized human eggs and, as such, the patent offended public morality, threatened public order and contravened legislation that prohibits the industrial use of human embryos. In 2006 the federal patent court ruled in Greenpeace's favour. Brüstle then appealed the case by taking it to the federal supreme court.

Supreme-court judge Peter Meier-Beck said on 12 November that he needed more legal clarity before his court could make a decision. Because German patenting laws for biotechnology are closely based on European Union guidelines, the view of the European court would give the final decision, he said. Greenpeace's patent specialist, Christoph Then, admits MeierBeck's ruling means that the case "is not running in our direction".

Brüstle says: "It's crazy that you are allowed to work on some hES cell lines in Germany and develop them for clinical purposes, but patenting your methods is deemed to be contrary to public order. Consultation with the European Court of Justice will hopefully contribute to harmonization of patent practice in Europe."

Alison Abbott 